\title{
OBNOVA KONANIA PRED ÚSTAVNÝM SÚDOM SLOVENSKEJ REPUBLIKY NA ZÁKLADE ROZSUDKU EURÓPSKEHO SÚDU PRE LUDSKÉ PRÁVA
}

REOPENING OF PROCEEDINGS BEFORE THE CONSTITUTIONAL COURT OF THE SLOVAK REPUBLIC FOLLOWING A JUDGMENT OF THE EUROPEAN COURT OF HUMAN RIGHTS

\section{Marica Pirošíková1}

DOI: https://doi.org/10.24040/pros.13.11.2020.svp.233-245

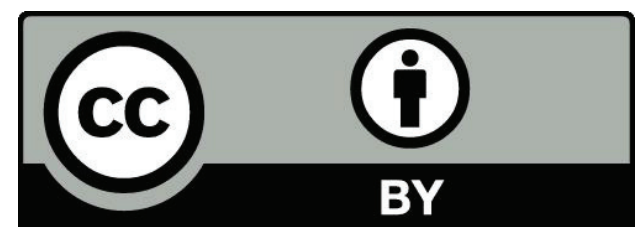

\begin{abstract}
Abstrakt
$V$ príspevku sa autorka venuje rozhodovacej činnosti Ústavného súdu Slovenskej republiky z hladiska medzinárodnej kontroly vykonávanej Radou Európy. Analyzuje relevantnú právnu úpravu a prax pokial' ide o obnovu konania pred Ústavným súdom Slovenskej republiky na základe rozsudku Európskeho súdu pre l’udské práva, a to predovšetkým z pohl'adu požiadaviek formulovaných Výborom ministrov Rady Európy.
\end{abstract}

Kl’účové slová

Európsky súd pre l’udské práva, Výbor ministrov Rady Európy, obnova konania pred ústavným súdom, výkon rozsudku Európskeho súdu pre l’udské práva

\begin{abstract}
The author's paper deals with the case-law of the Constitutional Court of the Slovak Republic from the point of view of international supervision exercised by the Council of Europe. It analyzes the relevant legislation and practice regarding the reopening of proceedings before the Constitutional Court of the Slovak Republic following a judgment of the European Court of Human Rights, especially in view of the requirements formulated by the Committee of Ministers of the Council of Europe.
\end{abstract}

\footnotetext{
${ }^{1}$ JUDr. Marica Pirošíková pôsobí na ako doktorandka na Katedre občianskeho a pracovného práva Univerzity Mateja Bela. Zároveň je advokátka. Od ukončenia Právnickej fakulty Univerzity Komenského v Bratislave v roku 2000 pôsobila v Kancelárii zástupcu Slovenskej republiky pred Európskym súdom pre l’udské práva, v rokoch 2002 až 2007 ako spoluzástupkyňa a od roku 2007 do roku 2020 ako zástupkyňa Slovenskej republiky v konaní pred Európskym súdom pre l'udské práva.
} 


\section{PRÁVNE ROZPRAVY ON-SCREEN II. - Sekcia verejného práva}

online vedecká konferencia - 13. november 2020

\section{Keywords}

European Court of Human Rights, Committee of Ministers of the Council of Europe, reopening of proceedings before the Constitutional Court, execution of judgment of the European Court of Human Rights

\section{Úvod}

Obnova konania pred Ústavným súdom Slovenskej republiky (d’alej len „ústavný súd“) bola vyvolaná potrebou prijat' Výborom ministrov Rady Európy (d’alej len „VM RE“) požadované individuálne opatrenia s ciel’om vykonat' rozsudky Európskeho súdu pre l'udské práva (d’alej len „ESLP“) o porušení l'udských práv st’ažovatel’ov, ku ktorým došlo zo strany ústavného súdu. Vychádzajúc z princípu subsidiarity je od týchto prípadov potrebné odlíšit' situácie, ked' k porušeniu práv zaručených Dohovorom o ochrane l’udských práv a základných slobôd (d’alej len „Dohovor") došlo v konaní pred všeobecnými súdmi.

\section{Povinnost’ štátu zabezpečit' restutio in integrum}

Článok 46 Dohovoru zakotvuje záväzok zmluvných strán riadit’ sa právoplatným rozsudkom ESLP vo všetkých prípadoch, ktorých sú stranami, a dohl'ad nad výkonom zveruje VM RE. Dňa 19. januára 2001 VM RE schválil členským štátom Odporúčanie č. R (2000)2 o obnove alebo opätovnom prerokovaní niektorých prípadov na vnútroštátnej úrovni na základe rozsudkov ESL'P. V odporúčaní sa okrem iného uvádza, že skúsenosti VM RE pri vykonávaní dohl'adu nad výkonom rozsudkov ESL’P ukázali, že za určitých okolností obnova konania, resp. opätovné prerokovanie prípadu predstavuje najúčinnejší, ak nie jediný prostriedok na dosiahnutie restitutio in integrum. Odporúčanie sa zmieňuje predovšetkým o prípadoch, ked’ poškodená strana nad'alej trpí vážnymi negatívnymi dôsledkami spôsobenými sporným vnútroštátnym rozhodnutím, ktoré nie sú dostatočne napravené spravodlivým zadost’učinením a nemôžu byt' odstránené inak, než opätovným prerokovaním veci, resp. obnovou konania a rozsudok ESL'P vedie k záveru, že napadnuté vnútroštátne rozhodnutie je v merite veci v rozpore s Dohovorom, alebo zistené porušenie spočíva v procesných pochybeniach alebo nedostatkoch takej závažnosti, ktorá vrhá vážne pochybnosti na výsledok vnútroštátneho konania, ktoré bolo predmetom st’ažnosti. Dňa 28. septembra 2000 aj Parlamentné 


\section{PRÁVNE ROZPRAVY ON-SCREEN II. - Sekcia verejného práva}

online vedecká konferencia - 13. november 2020

zhromaždenie Rady Európy schválilo rezolúciu č. 1226 (2000) o výkone rozsudkov ESLPP, ktorou vyzvalo členské štáty Rady Európy na vnútroštátnu úpravu konania, ktorá by umožňovala prieskum pôvodných konaní v dôsledku odsudzujúcich rozsudkov ESLPP.

\section{Dôvody zavedenia možnosti obnovy konania pred ústavným súdom v Slovenskej republike}

Na príslušné odporúčania Rady Európy vyzývajúce členské štáty zaviest’ možnost' opätovného prerokovania veci na vnútroštátnej úrovni na základe rozsudku ESL'P, slovenský zákonodarca v roku 2005 reagoval jednak v rámci rekodifikácie Trestného poriadku (d’alej „TP“), jednak novelizáciou Občianskeho súdneho poriadku (d'alej „OSP“). Pokial' ide o rekodifikovaný TP (zákon č. 301/2005 Z. z.), ktorý nadobudol účinnost' 1. januára 2006, ustanovenie § 394 ods. 4 TP výslovne zakotvilo, že skutočnost'ou skôr neznámou a odôvodňujúcou povolenie obnovy konania je aj rozhodnutie ESLP, podl'a ktorého rozhodnutím prokurátora alebo súdu Slovenskej republiky alebo v konaní, ktoré mu predchádzalo, boli porušené základné l'udské práva alebo slobody obvineného, ak negatívne dôsledky tohto rozhodnutia nemožno inak napravit'. Pokial' ide o OSP, zákonom č. 341/2005 Z. z., ktorý nadobudol účinnost' 1. septembra 2005, bolo ustanovenie $§ 228$ OSP doplnené o možnost' účastníka návrhom na obnovu konania napadnút' právoplatný rozsudok aj v prípade, ak ESLP vo svojom rozsudku rozhodol alebo dospel k záveru, že rozhodnutím súdu alebo konaním, ktoré mu predchádzalo, boli porušené základné l’udské práva alebo slobody účastníka konania a závažné dôsledky tohto porušenia neboli odstránené priznaným primeraným finančným zadost’učinením. ${ }^{2}$

Skutočnost', že na základe uvedených odporúčaní orgánov Rady Európy nedošlo v slovenskom právnom poriadku aj k výslovnému zakotveniu možnosti obnovy konania pred ústavným súdom v prípade, ak by ESL'P bolo konštatované porušenie základného l'udského práva alebo slobody účastníka v konaní pred ústavným súdom, začala predstavovat' problém až 21. februára 2013, ked' bol ústavnému súdu doručený návrh úspešného st'ažovatel’a pred ESL'P Harabina na obnovu disciplinárneho konania vedeného na ústavnom súde pod sp. zn. PL. ÚS 92/2011. Navrhovatel' vo svojom návrhu na obnovu konania pred ústavným súdom poukázal

\footnotetext{
${ }^{2}$ V súčasnosti sú v tomto ohl’ade relevantné $§ 397$ v písm. d) CSP, príp. § 472 SSP.
} 


\section{PRÁVNE ROZPRAVY ON-SCREEN II. - Sekcia verejného práva}

online vedecká konferencia - 13. november 2020

na to, že proti predmetnému (odsudzujúcemu) rozhodnutiu ústavného súdu podal st'ažnost' ESLP, ktorý svojím rozsudkom vyslovil, že predmetným rozhodnutím ústavného súdu bol porušený článok 6 ods. 1 Dohovoru z dôvodu, že o jeho disciplinárnom previnení nerozhodoval nestranný súd. ESL'P zároveň zamietol nárok na náhradu majetkovej škody a priznal st’ažovatel'ovi 3000 eur z titulu nemajetkovej ujmy s tým, že pri výkone rozsudku sú štáty nielen povinné zaplatit' sumy priznané z titulu spravodlivého zadost'učinenia, ale aj prijat' d'alšie všeobecné a individuálne opatrenia. V predmetnom prípade by podl'a ESLPP bola najvhodnejšou formou nápravy obnova konania pred súdom spíňajúcim záruky nestrannosti. ESL’P v tomto ohl'ade poznamenal, že Ústava Slovenskej republiky (d’alej „ústava“) ani zákon o konaní pred ústavným súdom (d’alej „ZoúS“) výslovne neposkytujú možnost’ obnovy konania pred ústavným súdom. ZoúS však umožňuje ústavnému súdu aplikovat', ak je to vhodné, OSP a TP, ktoré poskytujú možnost' obnovy konania, ak ESL'P v rozsudku dospeje k záveru, že rozhodnutie súdu alebo konanie, ktoré mu predchádzalo, bolo v rozpore so základnými l’udskými právami alebo slobodami účastníka konania.

Názor pléna ústavného súdu na možnost’ obnovy konania pred ústavným súdom na základe ustanovenia $§ 31$ a ZoúS účinného v danom čase, ktoré na konanie pred ústavným súdom pripúšstalo primerané použitie ustanovení OSP, resp. TP, však nebol jednotný. Podl’a časti pléna ústavného súdu taký výklad ustanovenia § 31a ZoúS nebol možný, ked’že v zmysle článku 152 ods. 4 ústavy platí, že výklad a uplatňovanie ústavných zákonov, zákonov a ostatných všeobecne záväzných predpisov musí byt' v súlade s ústavou, pričom ústava $\mathrm{v}$ tom čase (v znení pred zmenou realizovanou ústavným zákonom č. 161/2014 Z. z.) v článku 133 ustanovovala, že proti rozhodnutiu ústavného súdu nemožno podat' opravný prostriedok. Ustanovenie článku 133 ústavy tak podl’a časti sudcov ústavného súdu vylučovalo podanie akéhokol'vek (riadneho či mimoriadneho) opravného prostriedku, ktorý by bolo možné uplatnit' proti rozhodnutiu ústavného súdu, a to bez ohladu na to, či by išlo o rozhodnutie pléna ústavného súdu alebo senátu ústavného súdu, a teda v dôsledku znenia článku 133 ústavy zastávala názor, že rozhodnutia ústavného súdu vo veci samej sú konečné a nezmenitel'né. Návrh st’ažovatel'a Harabina na povolenie obnovy konania bol preto zamietnutý uznesením ústavného súdu sp. zn. PL. ÚS 6/2013 z 29. októbra 2013 podl’a článku 131 ods. 1 ústavy, ako aj § 4 ods. 3 ZoúS.

Listom z 5. septembra 2013 (ktorý bol zaslaný na vedomie aj prezidentovi SR, predsedovi vlády SR, predsedovi NR SR a predsedovi Ústavnoprávneho výboru NR SR) 


\section{PRÁVNE ROZPRAVY ON-SCREEN II. - Sekcia verejného práva}

online vedecká konferencia - 13. november 2020

predsedníčka ústavného súdu upovedomila ministra spravodlivosti o tom, že ustanovenie článku 133 ústavy, ktoré vylučuje podanie opravného prostriedku proti rozhodnutiu ústavného súdu, ako ustanovenie právneho predpisu vyššej právnej sily v porovnaní s ustanoveniami OSP, TP a ZoúS, na ktoré poukázal ESLP vo svojom rozsudku z 20. novembra 2012, môže predstavovat' vzhl’adom na existenciu viacerých alternatív výkladu ústavného textu prekážku naplnenia záverov predmetného rozsudku ESL'P.

Dňa 3. apríla 2014 bol Slovenskej republike doručený list Odboru výkonu rozsudkov ESL'P, ktorý uviedol, že zobral na vedomie skutočnost', že napriek žiadosti st'ažovatel'a v prípade Harabin nedošlo k obnoveniu konania pred ústavným súdom, pričom upriamil pozornost' SR na judikatúru ESL'P a Odporúčanie VM RE č. R(2002)2 o obnove alebo opätovnom prerokovaní niektorých prípadov na vnútroštátnej úrovni na základe rozsudkov ESLP. Zároveň Odbor výkonu rozsudkov ESL’P požiadal o vyjadrenie, či má SR v úmysle prijat' opatrenia, ktoré umožnia obnovu konania v súlade s Dohovorom, judikatúrou ESLP, príp. akékol'vek iné opatrenia majúce za ciel' restitutio in integrum. V tomto ohl'ade upozornil na to, že d'alšie dva prípady Majchrák proti Slovenskej republike a Vrabec proti Slovenskej republike vyžadujú prijatie podobných opatrení. Vzhl'adom na uvedené skutočnosti sa predsedníčka ústavného súdu v máji 2014 opakovane obrátila na ministra spravodlivosti s návrhom na zváženie možnosti iniciovania potrebných legislatívnych zmien v právnom poriadku SR, ktoré by vo vzt'ahu k obnove konania pred ústavným súdom umožnili realizovat' požiadavky vyplývajúce z rozsudkov ESL'P, a to spôsobom, ktorý by vylučoval akékol’vek pochybnosti o jeho ústavnosti. ${ }^{3}$

\section{Zmena článku 133 ústavy a nadväzujúce legislatívne zmeny}

Na návrh skupiny poslancov došlo k zmene ústavy, ktorá bola prijatá NR SR 4. júna 2014 a účinnost' nadobudla 1. septembra 2014. Nový článok 133 ústavy znie: „Proti rozhodnutiu ústavného súdu nemožno podat' opravný prostriedok; to neplatí ak rozhodnutím

\footnotetext{
${ }^{3}$ K zavedeniu možnosti obnovy konania pred ústavným súdom pozri aj MACEJKOVÁ, I.: Obnova konania pred Ústavným súdom Slovenskej republiky ako prostriedok nápravy porušenia l'udského práva konštatovaného Európskym súdom pre l'udské práva. In: OROZS, L. - MAJERČÁK, T. (eds.). Ochrana ludských práv a základných slobôd ústavnými súdmi a medzinárodnými súdnymi orgánmi. III. ústavné dni, zbornik vedeckých prác z medzinárodnej vedeckej konferencie. Košice: UJPŠ, 2014, s. 7 - 19, PIROŠÍKOVÁ, M.: Obnova konania pred ústavným súdom. ZSP, 2020, č. 1, s. 2 -6.
} 


\section{PRÁVNE ROZPRAVY ON-SCREEN II. - Sekcia verejného práva}

online vedecká konferencia - 13. november 2020

orgánu medzinárodnej organizácie zriadeného na uplatňovanie medzinárodnej zmluvy, ktorou je Slovenská republika viazaná, vznikne Slovenskej republike povinnost'v konaní pred ústavným súdom znovu preskúmat’ už prijaté rozhodnutie ústavného súdu“.

Zmena „ZoúS“ zákonom č. 353/2014 Z. z. s účinnost’ou od 1. januára 2015 upravila nový typ konania pred ústavným súdom v podobe konania o obnove konania pred ústavným súdom ( $§ 75$ až 75b). V uvedených ustanoveniach boli špecifikované náležitosti návrhu na obnovu konania, procesná legitimácia na podanie takéhoto návrhu, lehota na jeho podanie, účastníci uvedeného konania a spôsob rozhodovania o takomto návrhu. Tieto ustanovenia stratili účinnost’ 28. februára 2019.

V novom ZoúS nadväzuje na článok 133 ústavy $§ 69$ o opravnom prostriedku, a devätnásta hlava zákona upravujúca obnovu konania pred ústavným súdom (§ 214 - § 220). Uvedené ustanovenia nadobudli účinnost' 1. marca 2019. V § 215 je upravená procesná legitimácia na podanie návrhu na obnovu konania, v § 216 sú upravené náležitosti návrhu na začatie konania, v § 217 lehota na podanie návrhu na obnovu konania, § 218 špecifikuje účastníkov konania a § 219 spôsob rozhodovania o návrhu na obnovu konania.

\section{Obnova konania pred ústavným súdom na základe rozsudku ESL’P z hl'adiska praxe Výboru ministrov Rady Európy}

Podl’a $§ 214$ ZoúS možno právoplatné rozhodnutie ústavného súdu napadnút' návrhom na obnovu konania pred ústavným súdom, ak rozhodnutím orgánu medzinárodnej organizácie vznikne Slovenskej republike povinnost' v konaní pred ústavným súdom znovu preskúmat' už prijaté rozhodnutie ústavného súdu. Takýto postup je možný za splnenia d’alších podmienok uvedených v § 215 a nasl. ZoúS. Návrh na obnovu konania pred ústavným súdom je oprávnený podat’ ten, kto bol vo veci uvedenej v $§ 214$ účastníkom konania pred ústavným súdom a v koho prospech orgán medzinárodnej organizácie rozhodol (§ 215 ZoúS).

Obnova konania pred slovenským ústavným súdom na základe rozsudku ESLPP je potrebná, ak nastala situácia o ktorej sa zmieňuje Odporúčanie č. R (2000)2 o obnove alebo opätovnom prerokovaní niektorých prípadov na vnútroštátnej úrovni na základe rozsudkov ESLPP. V tomto ohl'ade je významné, či st’ažovatel' aj po rozsudku ESL’P nad'alej trpí vážnymi negatívnymi dôsledkami spôsobenými sporným rozhodnutím ústavného súdu, ktoré nie sú 


\section{PRÁVNE ROZPRAVY ON-SCREEN II. - Sekcia verejného práva}

online vedecká konferencia - 13. november 2020

dostatočne napravené spravodlivým zadost'učinením alebo zistené porušenie spočíva v procesných pochybeniach alebo nedostatkoch takej závažnosti, ktorá vrhá vážne pochybnosti na výsledok konania pred ústavným súdom, ktoré bolo predmetom st’ažnosti. Ak taká situácia nastane, potom obnova konania pred ústavným súdom prichádza do úvahy v prípadoch, v ktorých ESL'P rozhodol o porušení l’udských práv st’ažovatel’ov, ku ktorým došlo zo strany ústavného súdu, ktorý bud’ rozhodoval ako jediná inštancia (rozsudok Harabin proti Slovenskej republike z 20. novembra 2012); či v prípadoch, v ktorých dospel ESL'P k záveru o porušení práv st’ažovatel'ov na prístup k ústavnému súdu (rozsudok Majchrák proti Slovenskej republike z 23. októbra 2012, rozsudok Ďurd'ovič a Trančiková proti Slovenskej republike zo 7. októbra 2014, rozsudok Franek proti Slovenskej republike z 11. februára 2014) alebo pokial' zistené porušenie vzhl'adom na jeho charakter nemožno napravit' obnovou konania pred všeobecnými súdmi (rozsudok Trančiková proti Slovenskej republike z 13. januára 2015). Povinnost' SR obnovit' konanie pred ústavným súdom teda nezávisí od toho, či ESL'P v rozsudku použije tzv. klauzulu o obnove konania. Pripomíname, že ESLPP nie je vo svojej rozhodovacej činnosti jednotný pokial' ide o používanie tejto klauzuly, pričom na viacerých stretnutiach venovaných tejto téme jeho sudcovia uviedli, že zjednotenie praxe ESL'P nemožno očakávat'. Ďalej zdôraznili, že nad výkonom rozsudkov dohliada VM RE, ktorý posudzuje dostatočnost' individuálnych a všeobecných opatrení prijatých štátom s ciel'om vykonat' rozhodnutie ESLPP a postupuje podl'a vyššie uvedeného odporúčania č. R(2002)2. Oporu v praxi VM RE preto nemá právny názor prof. Mazáka ${ }^{4}$, ktorý popiera možnost' obnovy pred ústavným súdom, ak v rozsudku ESL'P nie je zmienka o obnove konania pred ústavným súdom. Vzhl'adom na uvedené treba vyhodnotit’ doterajšiu prax ústavného súdu, ktorý obnovil konanie aj napriek absencii uvedenej klauzuly v odôvodnení rozsudku ESLP, ak to bolo nevyhnutné v záujme poskytnutia materiálnej ochrany práv st’ažovatel'ov za plne súladnú s dlhodobou praxou VM RE a s povinnost’ami SR vyplývajúcimi z článku 46 ods. 1 Dohovoru. Pripomíname v tejto súvislosti aj vyššie spomínaný list Odboru výkonu rozsudkov ESL'P z 3. apríla 2014, ktorý okrem prípadu Harabin, v ktorom ESLP tzv. klauzulu o obnove konania aplikoval, poukazoval na potrebu obnovy konania v súvislosti s prípadmi Majchrák proti Slovenskej republike (rozsudok ESL'P z 23. októbra 2012) a Vrabec proti Slovenskej republike (rozsudok ESL'P z 30. novembra 2010), v ktorých taká klauzula zo strany ESL'P použitá nebola. Ak by ústavný súd

\footnotetext{
${ }^{4}$ MAZÁK, J.: Obnova konania pred Ústavným súdom SR: Prvé skúsenosti, pochybnosti a jeden námet, In: Bulletin slovenskej advokácie, č. 11/2017, s. 24-29.
} 


\section{PRÁVNE ROZPRAVY ON-SCREEN II. - Sekcia verejného práva}

online vedecká konferencia - 13. november 2020

postupoval v súlade $\mathrm{s}$ uvedeným názorom prof. Mazáka, tak by to mohlo mat' v jednotlivých prípadoch za následok vyžadovanie alternatívnych opatrení požadovaných VM RE na vykonanie rozsudku ESLPP takých, ako je odškodnenie za stratu šancí v prípadoch, ak k obnoveniu vnútroštátneho konania nedôjde. Aj ked’ je pravdou, že text článku 133 ústavy mohol byt' naformulovaný inak, je úplne v rozpore so súčasnou praxou VM RE jeho názor, že extenzívny výklad senátov ústavného súdu je v rozpore $\mathrm{s}$ účelom tohto mimoriadneho opravného prostriedku. Práve obnovenie konania pred ústavným súdom v uvedených prípadoch malo za následok prijatie záverečnej rezolúcie VM RE.

Obnova konania pred ústavným súdom bola prvýkrát povolená nálezom ústavného súdu sp. zn. III. ÚS 347/2015 z 27. októbra 2015 na základe rozsudku ESLP v prípade Ďurd'ovič a Trančiková proti Slovenskej republike (rozsudok zo 7. októbra 2014). ESLP v ňom dospel k záveru o porušení práva st’ažovatel'ov na prístup k ústavnému súdu tým, že tento najskôr odmietol ich ústavnú st’ažnost' z dôvodu, že nebolo podané dovolanie a po podaní ústavnej st’ažnosti po vyčerpaní dovolania bola st’ažnost' odmietnutá pre zmeškanie lehoty. Vychádzajúc z odôvodnenia rozsudku ESL'P ústavný súd dospel k záveru, že v prerokovávanej veci boli splnené podmienky na obnovu konania, preto obnovu konania v napadnutom konaní povolil. Ústavný súd vychádzal z toho, že ESL’P identifikoval ako porušitel’a práve ústavný súd, d’alej $\mathrm{z}$ toho, že porušenie práva navrhovatel'ov na prístup $\mathrm{k}$ súdu bolo konštatované $\mathrm{v}$ súvislosti $\mathrm{s}$ rozhodnutím ústavného súdu $\mathrm{v}$ časti, $\mathrm{v}$ ktorej ústavný súd čast' st'ažnosti navrhovatel’ov odmietol z procesných dôvodov, preto nedošlo k meritórnemu posúdeniu ich argumentov. Za daných okolností bol ústavný súd toho názoru, že aj napriek absencii výslovného príkazu opätovného preskúmania napadnutého rozhodnutia ústavného súdu v odôvodnení rozsudku ESL'P je v záujme poskytnutia materiálnej ochrany práv navrhovatel'ov nevyhnutné, aby ústavný súd opätovne preskúmal ich pôvodné st'ažnostné námietky, ked’že neboli v napadnutom konaní preskúmané ústavným súdom z vecného hladiska, a zároveň konštatoval, že je to zároveň potrebné na dosiahnutie účelu obnovy konania. $\mathrm{V}$ nadväznosti na tieto zistenia $\mathrm{v}$ zmysle $§ 75 b$ ods. 2 ZoúS, účinného v danom čase, ústavný súd zrušil napadnuté uznesenie ústavného súdu a vec mu vrátil na d’alšie konanie. Aj na základe uvedených skutočností VM RE skonštatoval, že SR splnila svoj záväzok podl’a článku 46 ods. 1 Dohovoru a rozhodol o ukončení sledovania výkonu tohto prípadu rezolúciou CM/ResDH(2015)12 prijatou 3. marca 2016. 


\section{PRÁVNE ROZPRAVY ON-SCREEN II. - Sekcia verejného práva}

online vedecká konferencia - 13. november 2020

Ďalším príkladom povolenia obnovy konania na základe rozsudku ESLPP v prípade Trančíková proti Slovenskej republike (rozsudok zo 13. januára 2015) je nález ústavného súdu sp. zn. III. ÚS 650/2015 z 24. februára 2016. Aj v tomto prípade bol ústavný súd toho názoru, že napriek absencii výslovného príkazu opätovného preskúmania napadnutého rozhodnutia ústavného súdu v odôvodnení rozsudku ESL'P je v záujme poskytnutia materiálnej ochrany práv navrhovatel'ky nevyhnutné, aby ústavný súd opätovne preskúmal jej pôvodné st’ažnostné námietky. Ústavný súd povolil obnovu konania napriek absencii výslovného príkazu opätovného preskúmania napadnutého rozhodnutia ústavného súdu v odôvodnení rozsudku ESLP aj v prípade Franek proti Slovenskej republike (rozsudok zo 11. februára 2014) a to nálezom ústavného súdu sp. zn. II. ÚS 218/2016 z 11. mája 2016. ${ }^{5}$

V uvedených prípadoch teda st'ažovatelia nemali inú možnost' ako obrátit' sa svojimi žiadost’ami o obnovu konania priamo na ústavný súd. Vychádzajúc z princípu subsidiarity (sp. zn. II. ÚS 421/2012, sp. zn. III. ÚS 97/2018) je od týchto prípadov potrebné odlíšit' situácie, ked' k porušeniu práv zaručených Dohovorom došlo v konaní pred všeobecnými súdmi, pričom nápravu zisteného porušenia je možné zabezpečit' obnovou konania pred nimi. V takých prípadoch nie je správny výklad všeobecných súdov, ktoré zamietnu žalobu na obnovu konania s odkazom na obnovu konania pred ústavným súdom, pretože táto bola zavedená do právneho poriadku pre prípady, v ktorých porušovatel’om práv neboli primárne všeobecné súdy, ale ústavný súd, a nie pre prípady v ktorých možno nápravu dosiahnut' obnovou konania pred všeobecnými súdmi, a to napriek tomu, že tieto pred rozhodnutím ESL'P posudzoval aj ústavný súd na základe st’ažnosti podl’a článku 127 ústavy. Jeho rozhodnutie o neporušení práv je tak prelomené rozhodnutím ESL'P.

Uvedený právny názor potvrdzuje aj nedávne rozhodnutie ústavného súdu vo veci sp. zn. I. ÚS 380/2020. Ide o prípad st’ažovatel’a Adamča, ktorý bol úspešný v konaní pred ESLPP (rozsudok Adamčo proti Slovenskej republike z 12. novembra 2019). ESL'P dospel vo svojom rozsudku k záveru, že odsúdenie st’ažovatel'a v trestnom konaní bolo v rozhodujúcej miere založené na výpovedi svedka, tzv. kajúcnika, pričom ostatné dôkazy proti st’ažovatel'ovi boli iba nepriame a preukazovali spáchanie trestného činu iba vo väzbe na priamy dôkaz výpovede tohto svedka. Výpoved' tohto svedka nebola podl'a názoru ESLPP dostatočne preskúmaná, a to ako vo vzt’ahu ku všetkým skutkovým okolnostiam, tak aj vo vzt’ahu k výhodám ním získaným

\footnotetext{
5 Podrobnejšie k uvedeným prípadom pozri PIROŠÍKOVÁ, M.: Obnova konania pred ústavným súdom. ZSP, 2020 , č. 2 , s. $57-58$.
} 


\section{PRÁVNE ROZPRAVY ON-SCREEN II. - Sekcia verejného práva}

online vedecká konferencia - 13. november 2020

v iných trestných konaniach. Navyše, svedok bol sám zapojený do spáchania predmetného trestného činu vraždy. ESL'P d’alej rozhodol, že porušenie jeho práva na spravodlivé súdne konanie predstavovalo aj nedoručenie vyjadrenia prokurátora $\mathrm{k}$ odvolaniu a dovolaniu navrhovatel'a. St’ažovatel' sa následne obrátil na ústavný súd a žiadal o obnovu konania. Tento jeho návrh odmietol ako zjavne neopodstatnený, pričom inter alia uviedol: „zohl’adňujúc právne závery ESL’P vyjadrené v jeho rozsudku..., ako i vnútroštátnu právnu úpravu (čl. 133 ústavy, § 214 a nasl. zákona o ústavnom súde a $\S 393$ a nasl. Trestného poriadku), najvhodnejšiu formu nápravy vo veci navrhovatel'a predstavuje obnova jeho trestného konania podl'a § 393 a nasl. Trestného poriadku. Ústavný súd považuje na tomto mieste za potrebné zdôraznit', že inštitút obnovy konania pred ústavným súdom nemožno zamieňat’s inštitútom obnovy konania podl'a Trestného poriadku, čo okrem iného vyplýva aj z odlišnosti samotného predmetu konania o ústavnej st’ažnosti podl'a čl. 127 ústavy, ktorým je rozhodovanie o namietanom porušení základných práv a slobôd st’ažovatel’ov. ...Obnova konania pred ústavným súdom totiž predstavuje prostriedok nápravy iba vtedy, ak nie je možné dosiahnut nápravu prostredníctvom obnovy konania pred všeobecnými súdmi. ...prípad navrhovatel'a už na prvý pohlad nespadá pod uvedené možnosti a zároveň ani nepredstavuje výnimočnú situáciu, ked’ by z okolností veci vyplývalo, že obnova konania pred ústavným súdom je nevyhnutná, pretože nie je možné dosiahnut' nápravu prostredníctvom obnovy konania pred v̌̌eobecnými súdmi. “”

Pripomíname, že trestné konanie bolo prvýkrát obnovené na základe rozsudku ESL'P v prípade Klein v. Slovenská republika [pozri rezolúciou CM/ResDH(2011)156 prijatú 14. septembra 2011], d’alším prípadom bol Zachar a Čierny proti Slovenskej republike [pozri rezolúciu CM/ResDH(2016)294 prijatú 18. októbra 2016). Civilné konanie na základe rozsudku ESL'P bolo prvýkrát obnovené v prípade Paulik v. Slovenská republika [pozri rezolúciu CM/ResDH(2013)195 prijatú 26. septembra 2013]. Ako d’alšie príklady možno uviest' prípad Ringier Axel Springer, a. s. v. Slovenská republika [pozri rezolúciu CM/ResDH(2013)95 z 29. mája 2013] a Mráz a d’alší v. Slovenská republika [pozri rezolúciu $\mathrm{CM} / \operatorname{ResDH}(2018) 259$ zo 4. júla 2018]. ${ }^{6}$

\footnotetext{
${ }^{6}$ Bližšie pozri PIROŠÍKOVÁ, M.: Výkon rozsudkov Európskeho súdu pre l'udské práva formou obnovy konania. ZSP, 2017, č. 2, s. 58 - 65; PIROŠÍKOVÁ, M.: Výkon rozsudkov Európskeho súdu pre l'udské práva formou obnovy konania v Slovenskej republike. In.: SMEKAL, H. - VYHNÁTEK, L. a kol. Beyond Comliance. Implementace rozhodnutí medzinárodních lidskoprávních těles na národní úrovni. Praha: Wolters Kluwer ČR, 2018, s. $203-219$.
} 


\section{PRÁVNE ROZPRAVY ON-SCREEN II. - Sekcia verejného práva}

online vedecká konferencia - 13. november 2020

Zaujímavý vzhl'adom na vyššie uvedené je aj prípad, v ktorom ústavný súd nálezom sp. zn. I. ÚS 76/2016 povolil obnovu konania pred ústavným súdom na základe rozsudku COMPCAR, s. r. o. proti Slovenskej republike. ESL'P v ňom rozhodol o porušení článku 6 ods. 1 Dohovoru, konkrétne práva na spravodlivé súdne konanie a osobitne princípu právnej istoty, z dôvodu zrušenia právoplatného a vykonatel’ného rozsudku v prospech st’ažujúcej sa spoločnosti najvyšším súdom na základe mimoriadneho dovolania podaného generálnym prokurátorom na podnet druhého z účastníkov konania. Ústavný súd však následne st’ažnost' obchodnej spoločnosti COMPCAR, s. $r$. o v obnovenom konaní odmietol uznesením sp. zn. II. ÚS 421/2012 z 13. decembra 2016 ako predčasnú a to s odkazom na princíp subsidiarity poukazujúc na skutočnost', že st'ažovatel'ka podala na základe rozsudku ESL'P aj návrh na povolenie obnovu konania na okresný súd podl’a § 228 a nasl. OSP. Okresný súd obnovu konania povolil rozsudkom sp. zn. 11Co/114/2018 z 15. mája 2019, ktorý nadobudol právoplatnost' 2. augusta 2019 po tom, ako ho potvrdil Krajský súd v Košiciach. Naposledy uvedený prípad potvrdzuje správnost' dôsledného dodržiavania princípu subsidiarity $\mathrm{v}$ prípadoch, v ktorých je možné nápravu zabezpečit' nápravu obnovou konania pred všeobecnými súdmi. ${ }^{7}$

Návrh na obnovu konania pred ústavným súdom možno podat' do šiestich mesiacov odo dňa, ked' sa rozsudok ESL’P stal konečným, alebo od toho času, ked' návrh na obnovu konania pred ústavným súdom mohol byt’ uplatnený (§ 217 ZoúS).

Pokial' ide o rozhodovaciu činnost' ESLPP pripomíname, že prípady, ktorých podstata bola preskúmavaná $\mathrm{v}$ iných podobných prípadoch a viaže sa $\mathrm{k}$ nim ustálená judikatúra, prerokovávajú výbory troch sudcov. Ich rozsudky nadobúdajú právoplatnost' dňom vyhlásenia. Ostatné prípady prerokováva sedemčlenná komora. Jej rozsudky nadobúdajú právoplatnost' po troch mesiacoch od ich vyhlásenia, okrem prípadov, kedy strany vyhlásili, že nepožiadajú o opätovné preskúmanie veci vel'kou komorou ESL'P alebo naopak, ak jedna zo strán (alebo obe) požiada ESL'P o postúpenie veci vel'kej komore ESL'P. O takejto žiadosti rozhoduje panel piatich sudcov vel'kej komory ESLP. Žiadosti možno vyhoviet' len ak sa týka závažnej otázky výkladu alebo aplikácie Dohovoru alebo jeho protokolov alebo závažnej otázky všeobecného významu. Odmietnutím žiadosti o preskúmanie veci vel'kou komorou ESL'P rozsudok komory

\footnotetext{
${ }^{7}$ K uvedenej problematike bližšie pozri PIROŠÍKOVÁ, M..: Komentár k §-fom 69, 214 - 220. In: MACEJKOVÁ, I. - BARÁNY, E. - FIAČAN, I. - HOLLÄNDER, P. - SVÁK, J. a kol.: Zákon o Ústavnom súde Slovenskej republiky. Komentár. 1. Vydanie. Bratislava : C. H. Beck, 2020, s. $536-569$, s. $1386-1411$.
} 


\section{PRÁVNE ROZPRAVY ON-SCREEN II. - Sekcia verejného práva}

online vedecká konferencia - 13. november 2020

nadobudne právoplatnost'. V prípade jej akceptácie rozsudok nadobudne právoplatnost' v deň jeho vyhlásenia vel'kou komorou ESL'P. ${ }^{8}$

\section{Záver}

Obnova konania pred slovenským ústavným súdom bola vyvolaná potrebou prijat' VM RE požadované individuálne opatrenia s ciel’om vykonat' rozsudky ESL'P o porušení l'udských práv st’ažovatel'ov, ku ktorým došlo zo strany ústavného súdu, ktorý bud' rozhodoval ako jediná inštancia, či rozsudky ESLP, v ktorých dospel k záveru o porušení práv st’ažovatel'ov na prístup k ústavnému súdu alebo pokial' zistené porušenie vzhl'adom na jeho charakter nemožno napravit' obnovou konania pred všeobecnými súdmi. Povinnost' SR obnovit' konanie pred ústavným súdom nezávisí od toho, či ESL'P v rozsudku použije tzv. klauzulu o obnove konania, ale od toho, či nastala situácia o ktorej sa zmieňuje Odporúčanie č. R (2000)2 o obnove alebo opätovnom prerokovaní niektorých prípadov na vnútroštátnej úrovni na základe rozsudkov ESLPP adresované VM RE členským štátom. V tomto ohl'ade treba vyhodnotit' doterajšiu prax ústavného súdu, ktorý obnovil konanie aj napriek absencii uvedenej klauzuly v odôvodnení rozsudku ESL'P, ak to bolo nevyhnutné v záujme poskytnutia materiálnej ochrany práv st’ažovatel'ov za plne súladnú s dlhodobou praxou VM RE a s povinnost'ami SR vyplývajúcimi z článku 46 ods. 1 Dohovoru.

\section{ZOZNAM BIBLIOGRAFICKÝCH ODKAZOV}

\section{Kapitola v učebnici alebo monografii}

PIROŠÍKOVÁ, M.: Komentár k §-fom 69, 214 - 220. In: MACEJKOVÁ, I. - BARÁNY, E. FIAČAN, I. - HOLLÄNDER, P. - SVÁK, J. a kol.: Zákon o Ústavnom súde Slovenskej republiky. Komentár. 1. Vydanie. Bratislava : C. H. Beck, 2020, s. 536 - 569, s. 1386 - 1411.

\footnotetext{
${ }^{8}$ Bližšie k podmienkam prípustnosti návrhu na obnovu konania pred ústavným súdom PIROŠÍKOVÁ, M.: Obnova konania pred ústavným súdom. ZSP, 2020, č. 1, s. 2 - 6.
} 


\section{PRÁVNE ROZPRAVY ON-SCREEN II. - Sekcia verejného práva}

online vedecká konferencia - 13. november 2020

\section{Periodiká a zborníky}

MACEJKOVÁ, I.: Obnova konania pred Ústavným súdom Slovenskej republiky ako prostriedok nápravy porušenia l’udského práva konštatovaného Európskym súdom pre l'udské práva. In: OROZS, L. - MAJERČÁK, T. (eds.): Ochrana l’udských práv a základných slobôd ústavnými súdmi a medzinárodnými súdnymi orgánmi. III. ústavné dni. Zborník vedeckých prác z medzinárodnej vedeckej konferencie. Košice : UJPŠ, 2014, s. 7 - 19.

MAZÁK, J.: Obnova konania pred Ústavným súdom SR: Prvé skúsenosti, pochybnosti a jeden námet. In: Bulletin slovenskej advokácie, 2017, č. 11, s. 24 - 29.

PIROŠÍKOVÁ, M.: Výkon rozsudkov Európskeho súdu pre l’udské práva formou obnovy konania. In: ZSP, 2017, č. 2, s. $58-65$.

PIROŠÍKOVÁ, M.: Výkon rozsudkov Európskeho súdu pre l’udské práva formou obnovy konania v Slovenskej republike. In: SMEKAL, H. - VYHNÁTEK, L. a kol. Beyond Comliance. Implementace rozhodnutí medzinárodnich lidskoprávních těles na národní úrovni. Praha: Wolters Kluwer ČR, 2018, s. 203 - 2019.

PIROŠÍKOVÁ, M.: Obnova konania pred ústavným súdom. In: ZSP, 2020, č. 1, s. 2 - 6.

PIROŠÍKOVÁ, M.: Obnova konania pred ústavným súdom. In: ZSP, 2020, č. 2, s. 57 - 58. 